\title{
Historisk mulighed for tættere samarbejde
}

\section{Af Bertel Haarder}

Efter århundreders splittelse er der nu reelle muligheder for, at Norden kan få den vægt i verdenspolitikken, som vor samlede styrke berettiger til. Vi har intet at tabe og alt at vinde med et tættere udenrigs- og sikkerhedspolitisk samarbejde. Men det gælder om at handle, inden vinduet måske lukkes - igen.

Kunne Danmarks tragedier i 1814 og 1864 og sønderjydernes endnu større lidelser 1914-18 være undgået, hvis vi havde haft en nordisk alliance?

Hvorfor blev Norden ikke samlet i 1800tallet, da både Italien og Tyskland blev samlet? Skandinavismen var stærk, og de danske og svenske troner var ledige gang på gang. Ville en personalunion mellem Sverige og Danmark og fælles udenrigsog forsvarspolitik kunne have afskrækket både England, Rusland og Tyskland fra at ydmyge de nordiske riger?

Disse spørgsmål rejser sig uundgåeligt i dette jubilæumsår, hvor en righoldig jubilæumslitteratur afslører, hvor tilfældige de historiske forløb har været - og hvor kort afstanden er mellem succes og fiasko for den svage og splittede ledelse, der martrede Danmark gennem århundrederne.

Historikere elsker at beskrive alting som uundgåeligt. Hvad skal en historiker stille op med tilfældigheder, dumhed og snæversyn? Som $\mathrm{fx}$. da svenskerne havde valgt en dansk prins til tronfølger, som desværre faldt af hesten og døde af hjerteslag! Hvorefter det lykkedes en af Napoleons marskaller at blive kronprins i Sverige og vende sig imod Napoleon tidsnok til, at han som allieret kunne modtage Norge som erstatning for Finland (som Rusland havde taget)!

Var det den danske konges stædighed, der fik ham til at holde fast ved Napoleon? Var det hans angst for, at Danmark skulle blive løbet over ende sydfra, der endte med at gøre ham til den store taber? Eller var det stormagternes indbyrdes forståelse, der overlod Finland til Rusland, mod at Sverige fik Norge?

Historikeren Rasmus Glenthøj har det hele med, både tilfældighederne, dumhederne og snæversynet, i sin omfattende folkebog '1864'. Jeg kastede mig over den for selv at kunne danne mig et indtryk af, om denne nationale tragedie kunne være und-

Bertel Haarder er første næstformand i Folketinget og formand for Danmarks delegation til Nordisk Råd 
gået. Den endte med tabet af to femtedele af riget og efterlod 200.000 sønderjyder under fremmedherredømme. Af sidstnævntes børnebørn mistede 6.000 livet $\mathrm{i}$ skyttegravene i Første Verdenskrig. Den lille landsdel kom til at ofre flere sønners liv end hele Danmark under hver af de to slesvigske krige 1848-51 og 1864.

Forud var gået det totale kollaps, statsbankerotten og tabet af Norge og flåden under de lige så tragiske Englandskrige i begyndelsen af århundredet. Ikke sært, at undergangsstemningen prægede datidens beslutningstagere. Mange, inklusive D.G. Monrad, der som statsminister havde det direkte ansvar for nederlaget, havde tvivl om, hvorvidt Danmark overhovedet havde en fremtid, eller om den næste krig ville blive den sidste.

Danmark var oppe imod den preussiske ministerpræsident Otto von Bismarck, der som nutidens Putin dygtigt udnyttede den protyske bevægelse i Holsten og dele af Slesvig til at begrunde en udvidelse af Preussen mod nord. Anledningen blev det danske traktatbrud (Fællesforfatningen mellem Danmark og Slesvig), som fik stormagterne til at acceptere det preussisk-østrigske felttog og den lette sejr over en underlegen fjende, der var splittet og dårligt ledet.

Det skabte sejrsrus i hele det tysktalende Europa og medvirkede til Tysklands samling og senere overmod, hvad man kan se på den kæmpemæssige Siegessäule i Berlin, der blev besmykket med erobrede danske kanoner.

\section{Danmark helt alene}

Det første spørgsmål, jeg stillede, var: Hvorfor stod Danmark helt alene over for denne overmægtige stormagt. Hvorfor var det kun Tyskland og Italien, der blev samlet i 1800 tallet? Hvorfor blev Norden ikke samlet? Var det kun, fordi stormagterne, især Rusland, foretrak svage magter ved Østersøen og Nordsøen? Eller var der andre årsager?

Skandinavismen var relativt stærk i de indflydelsesrige kredse - stærkere end fx. samlingskræfterne i Italien. Sverige og Norge havde fælles konge, og de nordiske troner blev gang på gang ledige. Mindst to danske prinser kunne være blevet norsk-svensk konge, hvis ikke den ene som nævnt var faldet af hesten, og hvis ikke Frederik den Sjette havde været så stædig. Hverken Frederik den Sjette eller Frederik den Syvende fik sønner, der kunne overtage tronen. Tænk, hvis Frederik den Sjette ikke havde stillet sig i vejen for sin halvfætter, den senere Christian den Ottende i 1810, så han kunne blive svensk tronfølger. Til gengæld tilbød han at gøre den svensk-norske prins Oscar (senere Oscar den Anden) til dansk tronfølger, men denne afslog og henviste til sin bror kong Karl den Femtende - i hvert fald, hvis man skal tro Oscars erindringer.

Aviserne blev bestormet med skandinavistiske artikler under den Slesvigske treårskrig 1848-51. Sprogfolk var i fuld gang med at tilnærme retskrivningen mellem Sverige på den ene side og Danmark og Norge på den anden. Ak, ja, nu går det stik modsat!

Hvorfor i alverden blev en nordisk personalunion med fælles udenrigs- og forsvarspolitik ikke til noget, når så mange ønskede det? Hvorfor endte vi i stedet med Christian den Niende og glyksborgerne på den danske trone? (Forgængeren Frederik den Syvende ville have foretrukket en svensk prins.) $\mathrm{Og}$ hvorfor er skandinavismen lige siden blevet nedvurderet, næsten som arbejdet i Nordisk Råd og Ministerråd nu om dage.

Var forskellene for store? Nej. Forskellene var betydeligt større mellem nord og syd i Tyskland og endnu større mellem nord og syd i Italien. Hvad der manglede, var - med statsminister Monrads ord - et politisk geni, en nordisk Bismarck, der havde kunnet forene Skandinavien.

Det andet spørgsmål var: Hvorfor modsatte Danmark sig den deling af Slesvig og udskillelse af Holsten, som gentagne gange i det tragiske forløb kunne have reddet situationen for den del af riget, der var dansk. 
Statsminister Monrad skriver på et tidspunkt under de fejlslagne fredsforhandlinger til den danske chefforhandler, A.F. Krieger:

"Den tanke dukker bestandig op hos mig, om det ikke skulle være muligt ved helt og holdent af afstå Holsten at vinde Slesvig, eller i alt fald grænsen til Dannevirke og en nordisk union... Hos dynastiet her ville man vistnok støde på vanskeligheder, men jeg anser dem dog ikke for uovervindelige."

Allerede året forinden, i januar 1863, havde Monrad faktisk foreslået en nordisk union over for den svenske gesandt. Men i stedet endte han med at bøje sig for kongens (og Ruslands) modvilje mod at afstå det tyske Holsten.

Han afviste en sindelagsgrænse, fordi han, som folkestemningen krævede, ville have den historiske og symbolske Dannevirke-Slien-grænse. Han kunne efter alt at dømme have fået en grænse syd om Flensborg (Danmarks næststørste by). De, der støttede en deling efter sindelag, var typisk de samme, der støttede en nordisk union med undtagelse af Monrad.

Rasmus Glenthøj giver ikke noget endegyldigt svar på de to spørgsmål, men det fremgår dog, at den russiske zar og stædige, dynastisk tænkende danske konger fra Frederik den Sjette til Christian den Niende blokerede. De holdt - som deres kolleger i hele Europa - fast ved den dansk-tyske helstat inklusive det tyske Holsten - stik imod de nye nationale bevægelser, der lå bag det slesvig-holstenske oprør, skandinavismen og danske politikeres ønske om at skille Slesvig fra Holsten. De var lunkne over for en nordisk forbundsstat. Konger bryder sig ikke om at afstå dele af deres riger. Frederik den Sjette og Karl 14 Johan af Sverige 'hadede hinanden af et godt hjerte'.

Dermed være ikke sagt, at kong Christian den Niende var skyld i hele ulykken. Tværtimod. Hvis hans kurs havde været fulgt konsekvent, kunne krigen måske være undgået. Men så ville det slesvig-holstenske spørgsmål have været uløst, således som det var tilfældet efter den første Slesvigske Krig 1848-51. Han byggede på, hvad der havde været normen i århundreder og var klar til en delvis genindførelse af enevælden med personalunion mellem Danmark og Slesvig-Holsten, men den holdning havde helt klart ikke fremtiden for sig.

En nordisk union ville ligesom delingen af Slesvig og afståelsen af Holsten have imødekommet de nye nationale strømninger, der skyllede over Europa. Frankrig var entydigt for Skandinavismen.Det var ikke urealistisk. Det ville have været lykken for Danmark. Men ikke for de dynastisk tænkende kongehuse.

Mest ubegribelig, set med nutidens øjne, er Christian den Niendes modvilje mod at afstå det tyske Holsten, som jo udgjorde hele problemet. Han stod fast på den gamle helstat, hvor kongen og ikke folket ejede riget. Han ville ikke være den konge, der formindskede sit rige. Det var antagelig også derfor, han i sin nød tilbød Bismarck, at hele kongeriget kunne tilslutte sig det tyske forbund mod at forblive samlet.

Hans tankegang stillede sig i vejen for såvel delingen om en nordisk union. SverigeNorge ville næppe ønske en personalunion med Holsten og derved importere Danmarks evige problem, herunder Holstens medlemskab af det tyske forbund - med alle de muligheder for tysk indblanding, det ville give, jævnfør Ruslands aktuelle indblanding i Ukraine!

\section{Tilsammen er vi ikke små}

Så vidt det kontrafaktiske. Man kan til evig tid diskutere, om Nordens skæbne blev afgjort af tilfældigheder, politisk naivitet, royal dumstædighed eller underkastelse for stormagter (der ønskede et svagt Norden). Norden forblev splittet i to svage småstater, der blev til tre, der blev til fire og senere til fem småstater (plus tre selvstyrende områder) med tilhørende småstatsmentalitet. De måtte i større eller mindre grad indrette sig på den europæiske nødvendighed, 


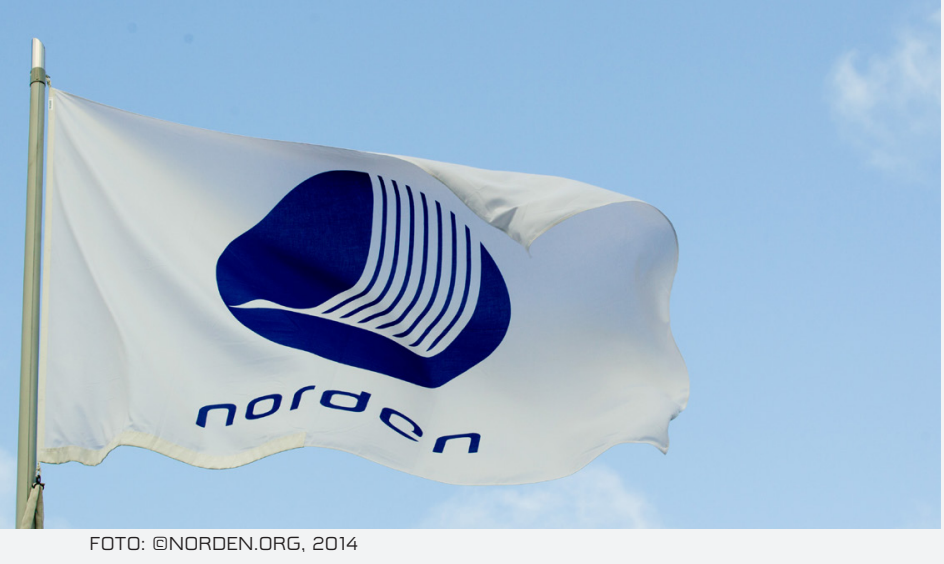
klub, G20.

der udgik fra stormagterne England, Rusland og senere Tyskland og Sovjet. Hvilket især gik ud over Danmark og Finland - og i særlig grad sønderjyderne.

Det er ikke tilstrækkelig forklaring, at de nordiske lande tilsammen var små og ikke havde mulighed for at forsvare sig imod stormagterne. Tilsammen er vi nemlig ikke små!

Jeg ved ikke præcis, hvordan det forholdt sig med størrelses- og styrkeforholdene gennem alle de seneste 200 år. Men jeg ved, at de nordiske lande i dag tilsammen har det 10. eller 11. største nationalprodukt i verden, et nationalprodukt, der er større end Ruslands, hvortil kommer, at vi tilsammen har den største handelsflåde i verden og den største udviklingshjælp i verden samt de største flystyrker i EU, større end Frankrigs, større end UK's.

Hvis vi havde fælles udenrigs- og forsvarspolitik, ville vi være et toneangivende medlem af de store landes klub, G20. Også fordi den nordiske samfundsmodel har vist sig så overordentlig levedygtig med topplaceringer i internationale sammenligninger, både når det gælder økonomisk styrke, stabilitet, ikke-korruption og en massiv borgertilfredshed, der bl.a. skyldes, at vore samfund bygger på tillid - gensidig tillid og tillid til statsmagten. For slet ikke at nævne nordiske film, litteratur, kunst, mu- sik, mad, design og mode, der nu i modsætning til tidligere er blevet kendt over store dele af verden.

Vi ser det ikke selv som en enhedskultur, men det gør omverdenen. Det kom frem, da kuratoren for Kennedy Centret i Washington i forbindelse med den nordiske kunstudstilling 'Nordic Cool' konstaterede: "Jeg anstrengte mig virkelig for at identificere forskelle i de kunstneriske udtryk mellem de forskellige nordiske lande. Men jeg fandt ingen. Det er forbløffende!”

Set under ét, er der hverken militære, økonomiske eller kulturelle grunde til, at de nordiske lande skal stå med hatten i hånden og føle sig underlegne over for de store. Og - hvad der især er relevant for Danmark: Der er ingen som helst undskyldning for, at vi ikke tager vor del af ansvaret for at sikre frihed og fred i verden.

Præsident Obamas venlige kompliment til Danmark om, at vi har 'punched above our weight' er mildt sagt en sandhed med modifikationer.

Især Danmark har indtil for nylig konsekvent 'punched below our weigt', og vi har tilmed brugt lidenheden som en bekvem undskyldning for ikke at tage vores rimelige del af slæbet med at redde Europa fra nazistisk og kommunistisk diktatur. Det kompenserer vi for i disse år ved at være usædvanligt akti- 
ve i verdens brændpunkter. Men det er noget helt nyt og måske kortvarigt.

Hvad gør vi så nu i Norden med vore rige potentialer? Den nye verdensorden gør alting muligt.

Splittede er vi: Tre af de fem lande er med i NATO, tre lande i EU. Kun Danmark er med begge steder, men har til gengæld de ulyksalige EU-forbehold, der blandt andet bevirker, at Danmark, i modsætning til Sverige, Finland - og Norge - ikke kan være med i EU's forsvarssamarbejde.

Nytter det overhovedet at tale om nordisk forsvarssamarbejde? Mange trofaste NATO-tilhængere siger nej. Det gælder også tidligere udenrigs- og forsvarsministre, der ikke kan fortrænge deres velbegrundede modvilje mod tidligere tiders venstrefløjssnak om Norden som et alternativ til Nato og EU, Norden som atomvåbenfri zone osv.

Men de tager fejl. Det er gammeltænkning. Der er i disse år ingen hindringer for nordisk forsvarssamarbejde. Heller ikke, selv om Nato-pagtens $\$ 5$ naturligvis kun sikrer 'rigtige' Nato-lande assistance i tilfælde af krig.

Det kom klart frem under et møde i Forsvarsministeriet med deltagelse af Folketingets Forsvarsudvalg og Delegationen til Nordisk Råd. Vi fik den klare besked, at det er os politikere, der sætter grænsen for, hvor meget der kan og skal samarbejdes om at styrke og/eller billiggøre forsvaret i Norden.

Anledningen var den nye enighed mellem alle fem lande om den nye fælles nordiske overvågning af det islandske luftrum, som gang på gang var blevet krænket af russiske fly. Da nogle af skeptikerne stillede spørgsmål ved, om NATO-lande og neutrale lande på den måde kunne samarbejde, fik jeg undersøgt sagen i NATO og fik meget klar besked. Der er ingen NATO-problemer i den fælles luftovervågning, så længe vi husker at kalde det 'overvågning' (surveillance) og ikke 'bevogtning' (policing).

Hvordan skulle det også kunne være et problem, at neutrale lande med deres betydelige luftstyrker yder bistand til en så kostbar opgave som at overvåge det store islandske territorium.

Den samme model kunne naturligvis bruges i Grønland. Den grønlandske landsstyreformand foreslog på Nordisk Råds Session i Oslo i efteråret 2013 en fælles nordisk drone-eskadrille. Men også her er jeg stødt på gammeltænkning. "Jamen, Grønland er jo vores", som en dansk diplomat udtrykte det. Ja, og hvad så? Hvad er problemet?

\section{Sverige og Finland}

Svenskerne ser ikke noget problem. De er i forvejen totalt afhængige af NATO. Deres egen forsvarschef Sverker Göransen har åbent erkendt, at det svenske forsvar kun kan holde Sverige i en uge!

Det er en af grundene til, at den svenske udenrigsminister Carl Bildt på Nordisk Råds session i Folketingssalen i november 2011 holdt en visionær tale om mulighederne for et fremtidigt nordisk forsvarssamarbejde. Han blev ganske vist afbrudt efter 3 minutter, som var taletiden. Han protesterede og sagde: "Jeg har noget vigtigt at sige!" Men lige meget hjalp det. Jeg gik over til ham og fik manuskriptet, som jeg siden har omdelt og omtalt vidt og bredt.

"Jamen, er det ikke bare, fordi svenskerne gerne vil sælge os deres fly?", lyder det fra skeptikerne. Men det bestemmer vi andre jo suverænt. Det er meningsløst på forhånd at udelukke svenske 'Gripen', omend valget naturligvis skal ske efter strengt objektive kriterier, og Norge har allerede valgt det amerikanske F 35, Joint Strike Fighter.

Siden har Folketingets Forsvarsudvalg fået lange lister over nye samarbejdsområder, fælles indkøb, fælles uddannelse, fælles transportkapacitet, fælles aktioner, fælles hovedkvarter i Afrika osv. Det foregår på bedste pragmatiske vis uden forpligtelse til, at alle skal deltage $\mathrm{i}$ alt.

NORDEFCO er blevet rammen om forsvarssamarbejdet, og der er ingen tvivl om, at det kan og vil blive udviklet i fremtiden. 
Men hvad så med Finland? Hvad siger den bidske russiske bjørn? Den knurrer, men det forhindrer ikke den nye finske statsminister Alexander Stubb i åbent at vedgå, at han er tilhænger af finsk Nato-medlemskab. Det samme er forsvarsministeren og den nye finske præsident Sauli Niinistö. Der er ganske vist flertal imod NATO-medlemskab i befolkningen, men der er samtidig et flertal, der ifølge meningsmålinger måske kan overbevises, hvis politikerne peger i den retning.

En rapport fra det polske udenrigspolitiske institut Pism hævder, at situationen i Ukraine har ført Finland nærmere NATO. Ifølge referatet i det finske Hufvudstadsbladet fra 3. juli i år vurderer Pism, at "Finland i nuläget främst samarbetar med de andre nordiske länderna og EU, men betoner att behovet av et NATO-medlemskab kan oppstå med kort varsel. Rysslands växande beredskab att använda styrka, landets ökade militäre potential og förmåga at genomföre en överraskningsattack samt dess grova hot mot Finland kommer at leda till att finska myndigheter söker pålitliga säkerhetgarantier."

Det må jo også forekomme mærkeligt i længden at fastholde neutraliteten, mens NATO med massiv folkelig opbakning (og danske fly) sikrer nabolandene Estland, Letland og Litauen mod den skæbne, som er blevet Ukraine, Georgien og Moldova til del.

Vi danskere skal dog være de sidste til at bebrejde finnerne og svenskerne, at de ikke bare afholder folkeafstemninger og melder sig ind i NATO. Vi, der stadig fastholder de absurde EU-forbehold uanset de skader, de forvolder. Det er svært for politikere at bede vælgerne gå imod alle de argumenter, som de selv samme partier har leveret i årtier. I et mangepartisystem vil der altid være partier, der vil udnytte den situation - i Finland især det frembrusende Centerparti, Urho Kekkonens gamle neutralistiske parti. Derfor hænger Danmark på forbeholdene, og derfor hænger Sveri- ge og Finland på neutraliteten. Men netop derfor er det så bekvemt for de svenske og finske politikere at integrere deres lande $i$ et stadigt tættere nordisk forsvarssamarbejde og derved de facto bringe deres lande så tæt på Nato som muligt. Hvilket også er en klar dansk interesse. Jo mere samarbejde, jo stærkere de facto-medlemskab.

Det er ikke noget problem for NATO, at Sverige og Finland ikke er omfattet af den militære bistandsforpligtelse i NATO-Pagtens $\$ 5$. Men det kan naturligvis være et problem for dem selv, som ikke løses fuldt ud gennem deres facto-medlemskab af NATO.

\section{Revolution}

For Nordisk Ministerråd og Nordisk Råd er det intet mindre end en revolution, at udenrigs- og forsvarssamarbejde nu er blevet det måske allervigtigste samarbejdsområde. Der er ganske vist ikke noget egentligt udenrigs- og forsvarsministerråd, og Nordisk Råd har fortsat ikke noget udenrigs- og forsvarsudvalg. De pågældende emner drøftes på udenrigsministermøderne og i Nordisk Råds Præsidium, hvor jeg i øvrigt gentagne gange sammen med den liberale Midtergruppe forgæves har stillet forslag om et udenrigs- og forsvarsudvalg eller en arbejdsgruppe. I stedet afholdes nu en årlig rundbordskonference om forsvarssamarbejdet med parlamentarikere, ministre, topembedsmænd og repræsentanter for forsvarsledelserne.

Jeg husker klart tidligere finske statsministre, der indædt, næsten forbitret, i Nordisk Råd og Ministerråd afviste enhver tale om udenrigs- og forsvarspolitik i Nordisk sammenhæng. Nu er alting forandret. Berlinmurens fald åbnede døren, og den er ikke blevet lukket trods russiske rumlerier og trusler over for Finland.

Den tidligere norske udenrigsminister Thorvald Stoltenberg skrev for fire år siden opskriften på et kommende nordisk udenrigs- og forsvarssamarbejde. Da han præsenterede sine 13 forslag, fik de ikke udelt 
god modtagelse i et notat udarbejdet af det danske udenrigsministerium. Jeg var opbragt over den noget negative holdning og gik til udenrigsminister Per Stig Møller, der heldigvis havde en langt mere positiv holdning. Siden er de 13 forslag blevet ledestjernen i det nordiske samarbejde.

Da Thorvald Stoltenberg i maj 2014 talte om de 13 forslag på Christiansborg, kunne han dog ikke skjule sin skuffelse over, at visse punkter tilsyneladende syltes. Det gælder beredskabsområdet og især ambassadesamarbejdet, som han synes er blevet til alt for lidt. I Berlin er der en fælles grøn havemur omkring de nordiske ambassader, men slet ikke det samarbejde, han forestiller sig. Han begriber ikke, at man ikke kan finde ud af at varetage hinandens interesser i de tilfælde, hvor der ikke er interessemodsætninger. Han mener, at en ambassadør udmærket også kan optræde som ambassadør for et andet land. Når EU kan have fælles ambassadører for 28 lande, når det gælder EU-anliggender, så kan Norden vel også finde ud af et tættere samarbejde om fælles anliggender.

\section{Nationale interessekonflikter}

Det er ikke de nationale interesser, der stiller sig i vejen. Det er måske nærmere udenrigsministerierne, der har en naturlig frygt for, at et tættere ambassadesamarbejde kan føre til yderligere besparelser og reduktion i antallet af topstillinger og avancementsmuligheder. Men resultatet kan jo lige så godt blive forbedringer for de nordiske borgere og virksomheder, der i dag oplever, at deres lands ambassade lukker i det ene land efter det andet.

I Burma er Norge og Danmark gået sammen. Og lignende samarbejder er på vej i Pakistan og Fjernøsten samt i Island. Men det går meget langsomt. Og det er ikke borgerne og virksomhederne, der har noget imod det.

Et nordisk forsvarssamarbejde har tidligere været på tale, men der har altid væ- ret nogen, der ikke ville være med. I 30'erne var det statsminister Thorvald Stauning, der udtalte, at Danmark ikke ville være 'Nordens lænkehund mod syd'. Et nordisk forsvarsforbund var næppe bekvemt for hans SR-regering, der i stedet satsede på nedrustning og underkastelse over for det mægtige Tyskland.

\section{Nordisk Råd}

Efter besættelsen af Danmark og Norge opstod tanken igen, stærkt støttet af den danske statsminister Hans Hedtoft, hvis hjerte brændte for det nordiske (og meget symbolsk døde under Nordisk Råds Session i Stockholm i 1955). Men Sovjetunionen tvang Finland til at stå udenfor, og så ville Sverige heller ikke med, hvorefter Norge og Danmark hurtigt smuttede ind under NATOs beskyttende paraply.

Som et plaster på såret blev Nordisk Råd etableret i 1952 med et budget for især kultur og undervisning. Men enhver tale om udenrigs- og forsvarspolitik var forbudt.

Med opløsningen af Sovjetunionen blev der pludselig åbnet et 'window of opportunity'. Nu kunne vi pludselig få det hele. Men det har taget tid at komme ud af vanetænkningen.

Forhåbentlig kender Norden sin besøgelsestid, før vinduet eventuelt lukkes igen. Vi har intet at tabe og alt at vinde. Et tættere forsvarssamarbejde vil muliggøre styrkelse (smart defense) og/eller besparelser på forsvaret. Det vil øge respekten for de nordiske lande. Det vil muliggøre, at vi ikke længere skal punche 'below our weight', men i stedet kan indtage den rolle i verdenspolitikken, som vor reelle styrke berettiger til.

Det kan naturligvis ikke undgå at stimulere et tættere udenrigspolitisk samarbejde. Så meget, des bedre. Når den erfarne nordmand og NATO-mand Thorvald Stoltenberg ikke ser problemer ved det, så er det svært at forestille sig, at der med styrke kan argumenteres imod det.

Og, jeg gentager, et tættere nordisk samarbejde er ikke på nogen måde i strid med 
vort EU- eller NATO-medlemskab, endsige ildeset i USA. Det kan man bl.a. se af amerikanernes interesse i dialog med de nordiske statsministre og NB8 (de nordisk-baltiske lande) og tilsvarende signaler fra lande som Storbritannien og Japan. Med Anders Ljunggrens ord i Nordisk Kontakt, hæfte 1, 2014 (han er journalist og svensk ambassadør i Estland):
"Den tid er emellertid forbi, förutom för et ytterligt fåtal individer, när EU- og Natomedlemskab sågs som alternativ til nordisk samarbete. Liksom individer i dag kan ha dubbla medborgerskab og förankring i flere nationaliteter, så är det i dag normalt för staters företrädere att oppträda med multipla identiteter." 